CORRECTION

\title{
Correction to: Quantifying the effects of hydrogen on carbon assimilation in a seafloor microbial community associated with ultramafic rocks
}

Ömer K. Coskun, Aurèle Vuillemin (D, Florence Schubotz (D), Frieder Klein (D), Susanna E. Sichel, Wolfgang Eisenreich (D) and William D. Orsi iD

(c) The Author(s) 2021

The ISME Journal (2022) 16:900; https://doi.org/10.1038/s41396-021-01087-6

Correction to: The ISME Journal https://doi.org/10.1038/s41396021-01066-x, published online 26 July 2021

The original version of this article unfortunately contained mistakes in references 85-91.

The original article has been corrected.

\begin{abstract}
(c) (i)
Open Access This article is licensed under a Creative Commons International License, which permits use, sharing, adaptation, distribution and reproduction in any medium or format, as long as you give appropriate credit to the original author(s) and the source, provide a link to the Creative Commons license, and indicate if changes were made. The images or other third party material in this article are included in the article's Creative Commons license, unless indicated otherwise in a credit line to the material. If material is not included in the article's Creative Commons license and your intended use is not permitted by statutory regulation or exceeds the permitted use, you will need to obtain permission directly from the copyright holder. To view a copy of this license, visit http://creativecommons. org/licenses/by/4.0/.
\end{abstract}

(c) The Author(s) 2021 